\title{
Erratum to: Biochar application to a fertile sandy clay loam in boreal conditions: effects on soil properties and yield formation of wheat, turnip rape and faba bean
}

\author{
Priit Tammeorg • Asko Simojoki • Pirjo Mäkelä • \\ Frederick L. Stoddard • Laura Alakukku • Juha Helenius
}

Published online: 29 March 2014

(C) Springer International Publishing Switzerland 2014

\section{Erratum to: Plant Soil (2014) 374:89-107 DOI 10.1007/s11104-013-1851-5}

The original version of this paper unfortunately contained errors.

In the Materials and methods section the description of the ash and elemental concentration of the biochar should be 'The ash content and the total elemental composition of the biochar were determined by dry ashing along the lines of Miller (1996). A $1.5 \mathrm{~g}$ sample was dry-ashed in a laboratory muffle furnace (Nabertherm Program Controller C19, Nabertherm, Lilienthal, Germany) by raising the temperature to $500{ }^{\circ} \mathrm{C}$ within $2 \mathrm{~h}$ and then keeping it at $500{ }^{\circ} \mathrm{C}$ for $3 \mathrm{~h}$. Next,

The online version of the original article can be found at http://dx.doi/ org/10.1007/s11104-013-1851-5.

P. Tammeorg $(\bowtie) \cdot$ P. Mäkelä · F. L. Stoddard · J. Helenius Department of Agricultural Sciences,

P.O. Box 27, Latokartanonkaari 5, Plant Production Sciences, FIN-00014 University of Helsinki, Finland e-mail: priit.tammeorg@helsinki.fi

\section{A. Simojoki}

Department of Food and Environmental Sciences, P.O. Box 27, Latokartanonkaari 11, Environmental Soil Science, FIN-00014 University of Helsinki, Finland

\section{Alakukku}

Department of Agricultural Sciences, P.O. Box 28, Koetilantie 5, Agrotechnology, FIN-00014 University of Helsinki, Finland the ash was transferred into an Erlenmeyer flask with $100 \mathrm{ml} 0.2 \mathrm{M} \mathrm{HCl}$, boiled for $30 \mathrm{~min}$, transferred quantitatively into a $100-\mathrm{ml}$ measurement flask, adjusted to the volume with deionised water, and filtered through a filter paper (Whatman, Grade 589/3, blue ribbon, pore size $2 \mu \mathrm{m}$, GE Healthcare, UK). When necessary, dilutions were carried out with $0.2 \mathrm{M} \mathrm{HCl}$. The total elemental concentrations of extracts were analysed by an inductively coupled plasma optical emission spectroscopy (ICP-OES; Thermo-Fisher iCAP3600 MFC Duo, Thermo Fisher Scientific, Cambridge, UK).

In the Results section, the sentences 'The $\mathrm{BC}$ had a BET SSA of $34.1 \mathrm{~m}^{2} \mathrm{~g}^{-1}, \mathrm{pH}\left(\mathrm{H}_{2} \mathrm{O}\right) 10.8$, ash content $104.1 \mathrm{~g} \mathrm{~kg}^{-1}$ and $\mathrm{VM}$ content $268.2 \mathrm{~g} \mathrm{~kg}^{-1}$. The contents of total $\mathrm{Ca}, \mathrm{K}$ and $\mathrm{N}$ were $44.4,32.3$ and $6.2 \mathrm{~g} \mathrm{~kg}^{-1}$, respectively.' should be 'The BC had a BET SSA of $34.1 \mathrm{~m}^{2} \mathrm{~g}^{-1}, \mathrm{pH}\left(\mathrm{H}_{2} \mathrm{O}\right) 10.8$, ash content $55.7 \mathrm{~g} \mathrm{~kg}^{-1}$ and $\mathrm{VM}$ content $268.2 \mathrm{~g} \mathrm{~kg}^{-1}$. The concentrations of total $\mathrm{Ca}, \mathrm{K}$ and $\mathrm{N}$ were $10.0,4.0$ and $6.2 \mathrm{~g} \mathrm{~kg}^{-1}$, respectively. In the Discussion section, the sentence 'Even though the application of $10 \mathrm{t} \mathrm{ha}^{-1} \mathrm{BC}$ provided approximately $10 \% \mathrm{C}$ addition to the native SOC content in topsoil, as well as notable amounts of easily soluble $\mathrm{K}, \mathrm{Ca}$ and Mn (183, 56 and $13 \mathrm{~kg} \mathrm{ha}^{-1}$, respectively)' should be 'Even though the application of $10 \mathrm{tha}^{-1} \mathrm{BC}$ provided approximately $10 \% \mathrm{C}$ addition to the native SOC content in topsoil, as well as notable amounts of total $\mathrm{Ca}, \mathrm{K}$, and $\mathrm{Mg}$ (100, 40 and $17 \mathrm{~kg} \mathrm{ha}^{-1}$, respectively)'.

In Online supplementary material, Table S 2 should be as follows: 
Table S 2. Physicochemical properties of the spruce chip biochar, means with standard deviation (SD).

\begin{tabular}{|c|c|c|c|}
\hline Property $^{\mathrm{a}}$ & Result total & SD & Unit \\
\hline BET SSA & 34.1 & 0.4 & $\mathrm{~m}^{2} \mathrm{~g}^{-1}$ \\
\hline $\mathrm{pH}_{\mathrm{H} 2 \mathrm{O}}$ & 10.8 & 0.2 & \\
\hline Ash & 55.7 & 1.6 & $\mathrm{~g} \mathrm{~kg}^{-1}$ \\
\hline VM & 268.2 & 28.6 & $\mathrm{~g} \mathrm{~kg}^{-1}$ \\
\hline $\mathrm{C} / \mathrm{N}$ & 142 & & \\
\hline $\mathrm{Al}$ & 0.45 & 0.01 & $\mathrm{~g} \mathrm{~kg}^{-1}$ \\
\hline $\mathrm{Ca}$ & 10.0 & 0.18 & $\mathrm{~g} \mathrm{~kg}^{-1}$ \\
\hline $\mathrm{Fe}$ & 2.9 & 0.07 & $\mathrm{~g} \mathrm{~kg}^{-1}$ \\
\hline K & 4.0 & 0.18 & $\mathrm{~g} \mathrm{~kg}^{-1}$ \\
\hline $\mathrm{Mg}$ & 1.7 & 0.02 & $\mathrm{~g} \mathrm{~kg}^{-1}$ \\
\hline $\mathrm{Mn}$ & 0.5 & 0.01 & $\mathrm{~g} \mathrm{~kg}^{-1}$ \\
\hline $\mathrm{Na}$ & 0.3 & 0.04 & $\mathrm{~g} \mathrm{~kg}^{-1}$ \\
\hline $\mathrm{P}$ & 1.1 & 0.02 & $\mathrm{~g} \mathrm{~kg}^{-1}$ \\
\hline S & 0.6 & 0.01 & $\mathrm{~g} \mathrm{~kg}^{-1}$ \\
\hline $\mathrm{C}$ & 878 & 40 & $\mathrm{~g} \mathrm{~kg}^{-1}$ \\
\hline $\mathrm{N}$ & 6.17 & 0.46 & $\mathrm{~g} \mathrm{~kg}^{-1}$ \\
\hline $\mathrm{Cd}$ & 0.30 & 0.004 & $\mathrm{mg} \mathrm{kg}^{-1}$ \\
\hline Co & 2.7 & 0.1 & $\mathrm{mg} \mathrm{kg}^{-1}$ \\
\hline $\mathrm{Cu}$ & 29.2 & 3.8 & $\mathrm{mg} \mathrm{kg}^{-1}$ \\
\hline $\mathrm{Ni}$ & 84.9 & 4.1 & $\mathrm{mg} \mathrm{kg}^{-1}$ \\
\hline $\mathrm{Pb}$ & 22.8 & 30.8 & $\mathrm{mg} \mathrm{kg}^{-1}$ \\
\hline $\mathrm{Sr}$ & 65.8 & 0.6 & $\mathrm{mg} \mathrm{kg}^{-1}$ \\
\hline $\mathrm{Zn}$ & 145.4 & 3.4 & $\mathrm{mg} \mathrm{kg}^{-1}$ \\
\hline
\end{tabular}

${ }^{\mathrm{a}} \mathrm{n}=2$ for $\mathrm{pH}$, total $\mathrm{C}$ and $\mathrm{N}, \mathrm{n}=6$ for $\mathrm{VM}$ and ash and $\mathrm{n}=3$ for other analyses. Abbreviations: BET SSA $=$ specific surface area; $\mathrm{VM}=$ volatile matter.

\section{References:}

Miller, R.O., 1998. High-temperature oxidation: dry ashing, in: Kalra, Y.P. (Ed.), Handbook of Reference Methods for Plant Analysis. 